\title{
Human cationic trypsinogen (PRSS1) variants and chronic pancreatitis
}

\author{
Balázs Csaba Németh and Miklós Sahin-Tóth \\ Department of Molecular and Cell Biology, Henry M. Goldman School of Dental Medicine, Boston University, Boston, \\ Massachusetts
}

Submitted 6 December 2013; accepted in final form 14 January 2014

\begin{abstract}
Németh BC, Sahin-Tóth M. Human cationic trypsinogen (PRSS1) variants and chronic pancreatitis. Am J Physiol Gastrointest Liver Physiol 306: G466-G473, 2014. First published January 23, 2014; doi:10.1152/ajpgi.00419.2013._Variations in the serine protease 1 (PRSS1) gene encoding human cationic trypsinogen have been conclusively associated with autosomal dominant hereditary pancreatitis and sporadic nonalcoholic chronic pancreatitis. Most high-penetrance PRSS1 variants increase intrapancreatic trypsin activity by stimulating trypsinogen autoactivation and/or by inhibiting chymotrypsin C-dependent trypsinogen degradation. Alternatively, some PRSS1 variants can cause trypsinogen misfolding, which results in intracellular retention and degradation with consequent endoplasmic reticulum stress. However, not all PRSS1 variants are pathogenic, and clinical relevance of rare variants is often difficult to ascertain. Here we review the PRSSI variants published since 1996 and discuss their functional properties and role in chronic pancreatitis.
\end{abstract}

\section{The PRSS1 Gene}

The serine protease 1 (PRSS1, PRoteaSe Serine 1) gene in humans is located on chromosome $7 \mathrm{q} 35$, within the $\mathrm{T}$ cell receptor beta locus (43). The association of trypsinogen genes with this locus is important historically, because DNA sequencing of this region in 1996 and the fortuitous finding of eight trypsinogen genes intercalated here greatly facilitated the discovery of the susceptibility gene for hereditary pancreatitis. PRSS1 codes for human cationic trypsinogen, the precursor for the most abundant digestive enzyme secreted by the human pancreas (45). Besides PRSS1, the locus also contains five trypsinogen pseudogenes, a relic gene, and PRSS2, that encodes anionic trypsinogen, the other major human trypsinogen isoform. The PRSS3 gene coding for mesotrypsinogen, the relatively minor third human isoform, is found on chromosome $9 \mathrm{p} 13$.

\section{Copy Number Mutations in PRSSI}

Heterozygous triplication and duplication of a $605-\mathrm{kb}$ segment containing the trypsinogen genes on chromosome 7 was found in French patients with hereditary and sporadic idiopathic chronic pancreatitis $(5,29,33)$. Presumably similar heterozygous duplications of PRSSI were reported in two U.S. families with hereditary pancreatitis (26). Such copy number mutations should result in higher trypsinogen expression through a gene-dosage effect, although this has not been demonstrated directly. Higher trypsinogen concentrations, in turn, would increase the likelihood of autoactivation and development of intrapancreatic trypsin activity. A unique duplication event that resulted in an extra copy of a hybrid PRSS2/ PRSS1 trypsinogen gene was also described in a French family with hereditary pancreatitis (34).

Address for reprint requests and other correspondence: M. Sahin-Tóth, $72 \mathrm{E}$. Concord St., Evans-433, Boston, MA 02118 (e-mail: miklos@bu.edu).

\section{Gene Conversions Within Trypsinogen Genes}

Human trypsinogen genes exhibit a high level of sequence identity, which may facilitate gene conversion events. In fact, gene conversion was suggested as a mechanism for the evolutionary origin of the most common hereditary pancreatitisassociated mutations (6). A gene conversion event was identified in a 6-yr-old German girl with sporadic chronic pancreatitis, which replaced exon 2 in PRSS1 with that from PRSS2 (60). A gene duplication event in a French family with hereditary pancreatitis resulted in a similar hybrid gene, containing exons 1-2 from PRSS2 and exons 3-4-5 from PRSS1 (34). Since exon 1 codes for part of the signal peptide which is removed in the endoplasmic reticulum, only changes in exon 2 affect the mature trypsinogen protein. The amino acids encoded by exon 2 are nearly identical between the two isoforms, with the exception of Ile29 and Ser54 found in anionic trypsinogen (PRSS2). Consequently, the hybrid genes described in the German and French studies encode cationic trypsinogen with mutations p.N29I and p.N54S. Whereas the p.N54S variation is functionally innocuous (60), the p.N29I mutation causes hereditary pancreatitis.

\section{Common Polymorphisms in PRSSI}

Polymorphic variations with a population frequency $>5 \%$ are relatively rare in PRSS1. Variant c. $486 \mathrm{C}>\mathrm{T}$ (p.D162 $=$ or p.D162D; dbSNP rs6666) in exon 4 and variant c.738C $>$ T (p.N246 = or p.N246N, dbSNP rs6667) in exon 5 are the only two variations within the coding region. The two variants are typically found in linkage disequilibrium and the $\mathrm{C}$ allele has a slightly higher frequency in Europeans (0.6), whereas it is less frequent ( 0.25 ) in subjects of Asian origin or subjects from India (0.1). No disease association has been demonstrated for either variant. Two additional common variants can be found in the $5^{\prime}$ region upstream of the ATG start codon: c. $-204 \mathrm{C}>\mathrm{A}$ (dbSNP rs 4726576; C allele frequency is $\sim 0.7$ in Europeans 
and $\sim 0.4$ in Asians) and c. $-408 \mathrm{C}>\mathrm{T}$ (dbSNP rs 10273639; C allele frequency is $\sim 0.6$ in Europeans and $\sim 0.3$ in Asians). In a recent genomewide association study, variant c. $-408 \mathrm{C}>\mathrm{T}$ (i.e., the $\mathrm{T}$ allele) was demonstrated to have a small protective effect against chronic pancreatitis presumably by lowering trypsinogen expression (64). The $\mathrm{C}$ allele of the same variation (erroneously reported as $-409 \mathrm{C} / \mathrm{T}$ ) was previously claimed to offer protection against pancreatic cancer in a Chinese population; however, independent confirmation is lacking (31).

\section{PRSSI Variants in the General Population}

Published accounts indicate that sequencing the PRSS1 gene of 200 French (7), 82 German (58), 420 Chinese $(4,68), 28$ Korean (30), and 150 Brazilian (3) control subjects revealed only the p.E79K exon 3 variant in a French and a Brazilian individual. More recently, exon 3 of 1,000 healthy controls of German origin was sequenced and only the p.V123L variation was identified in a single subject (46). These observations indicate that PRSS1 variants, other than the common polymorphisms, are exceedingly rare in the general population.

\section{PRSS1 Mutations in Hereditary Pancreatitis}

Autosomal dominant hereditary pancreatitis was first reported by Comfort and Steinberg in 1952 (10). Using genetic linkage analysis, three independent research groups localized the susceptibility gene to chromosome 7 in $1996(27,39,62)$. In the same year, Whitcomb et al. (63) used candidate gene sequencing to identify the most common causative mutation p.R122H in PRSS1. Genetic heterogeneity underlying hereditary pancreatitis was soon recognized when the second most common PRSS1 mutation, p.N29I, was described by two groups in 1997-1998 $(16,56)$. These two heterozygous mutations are found in $\sim 90 \%$ of hereditary pancreatitis families worldwide, with p.R122H accounting for $\sim 65 \%$ and p.N29I for $\sim 25 \%$ of the cases. In the remaining $10 \%$ of the cases, PRSS1 mutations p.A16V, p.D21A, p.D22G, p.K23R, p.K23_I24insIDK, p.N29T, p.V39A, p.R116C, and p.R122C were identified, always in the heterozygous state $(2,12,22,28,40,48,55,57,65,67)$. Mutations p.D21A, p.D22G, p.K23R, p.K23_I24insIDK, and p.V39A were found only in a single family each. Penetrance of PRSS1 mutations in hereditary pancreatitis families is incomplete; it is estimated between 80 and $90 \%$ for carriers of p.R122H, although smaller pedigrees may exhibit lower apparent penetrance $(21,62,41,49)$. Note that mutations p.A16V and p.R116C exhibit variable penetrance and were also found in sporadic cases with no family history.

Hereditary pancreatitis-associated PRSS1 mutations exert their effect via a so-called trypsin-dependent pathological pathway, which involves increased autoactivation of mutant trypsinogens resulting in elevated intrapancreatic trypsin activity. Rare mutations in the activation peptide of trypsinogen (p.D21A, p.D22G, p.K23R, and p.K23_I24insIDK) directly stimulate autoactivation $(8,15,22,37)$. In contrast, the more common hereditary pancreatitis-associated PRSSI mutations alter the regulation of activation and degradation of cationic trypsinogen by chymotrypsin C (CTRC), a digestive enzyme that controls trypsin levels generated through autoactivation of human trypsinogens (51) (Fig. 1). CTRC promotes degradation of trypsinogen by cleaving the Leu81-Glu82 peptide bond in the calcium binding loop and thereby attenuates trypsin levels during autoactivation $(51,52,53)$. Importantly, trypsin-mediated autolytic cleavage of the Arg122-Val123 peptide bond is also required for CTRC-dependent degradation and inactivation of trypsinogen $(51,53)$. Paradoxically, CTRC also stimulates trypsinogen activation by processing the activation peptide at the Phe18-Asp19 peptide bond to a shorter form, which is cleaved by trypsin at a higher rate, resulting in increased autoactivation $(38,51)$.

PRSS1 mutations interfere with the CTRC-mediated cleavages described above and render trypsinogen resistant to degradation and/or increase processing of the activation peptide (Fig. 1). Typically, a combination of two or more effects results in the common phenotype of increased activation (51). Thus mutations p.R122H and p.R122C completely block cleavage at $\operatorname{Arg} 122$ by trypsin but also decrease cleavage at Leu81 by CTRC. Mutation p.N29I increases cleavage of the activation peptide and reduces cleavage both at Leu81 and Arg122. Mutations p.V39A and p.N29'T decrease cleavage at Leu81 and Arg122, whereas mutation p.A16V increases processing of the activation peptide by CTRC $(38,51)$. Regardless of mechanistic details, the unifying biochemical phenotype of all hereditary pancreatitis-associated mutants is increased rates of autoactivation, with markedly elevated final trypsin activity levels, relative to wild-type cationic trypsinogen.

The only exception to the unifying pathological mechanism described above is mutation p.R116C, which does not change trypsinogen activation but causes misfolding, which results in intracellular aggregation and degradation and consequently reduced secretion (25). Mutation-induced misfolding can elicit endoplasmic reticulum stress, which is probably responsible for the increased disease risk in carriers of p.R116C, although the exact mechanism is unknown. Mutation p.R116C exhibits variable penetrance and is often found in sporadic cases, suggesting that the misfolding-dependent pathological pathway may confer relatively smaller risk.

\section{PRSS1 Variants in Sporadic Nonalcoholic Chronic Pancreatitis}

The first indication that PRSSI variants can cause chronic pancreatitis with lower penetrance came from the identification of the p.A16V variant by Witt et al. (65) in four children with chronic pancreatitis. Only one child had a positive family history consistent with hereditary pancreatitis, whereas in three children the disease was sporadic with no family history, even though inheritance from unaffected parents was demonstrated. Subsequent studies based on the EUROPAC database (18) confirmed the variable penetrance of this variant, demonstrating that p.A16V was found in six families with hereditary pancreatitis, in one family with familial (single-generation) chronic pancreatitis, and in three cases of chronic pancreatitis with no family history. The biochemical phenotype of the p.A16V explains its genetic properties: the mutation causes increased autoactivation in the presence of CTRC; however, the rate of autoactivation and the final trypsin levels attained are much lower than those observed with the highly penetrant PRSS1 mutations such as p.R122H (51). Increased autoactivation is due to faster processing of the mutant trypsinogen activation peptide by CTRC $(38,51)$. As noted above, mutation 
A

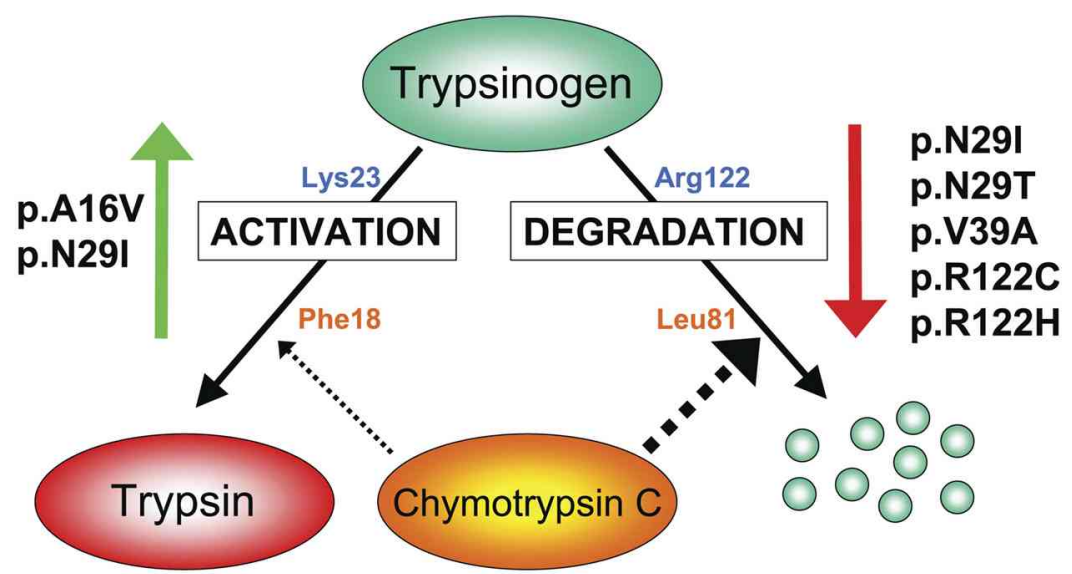

B

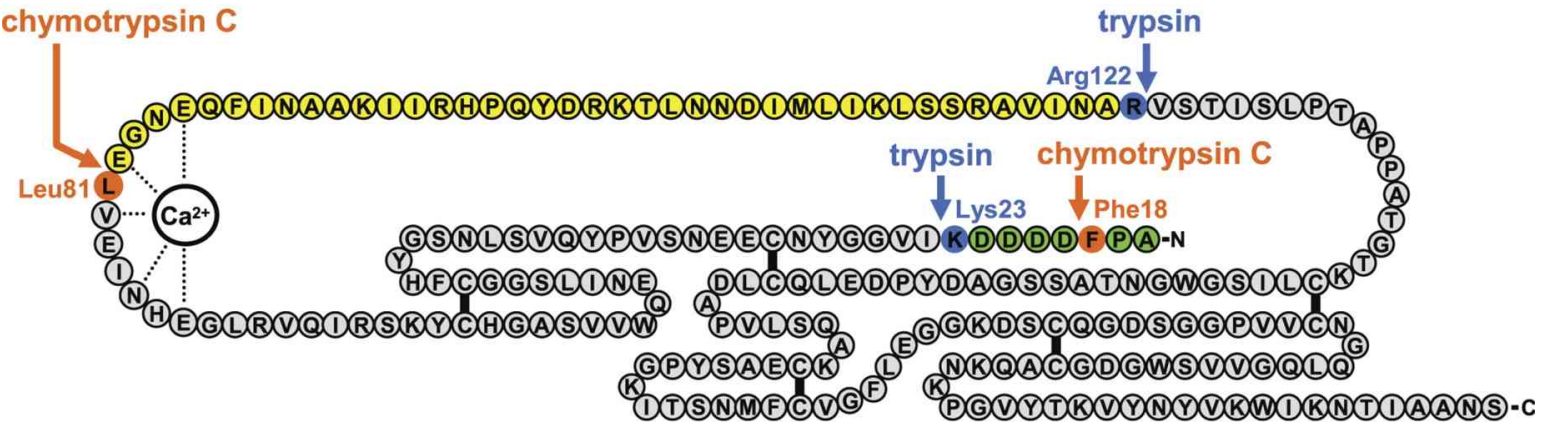

Fig. 1. Effect of pancreatitis-associated PRSS1 mutations on the chymotrypsin C (CTRC)-dependent activation and degradation of human cationic trypsinogen. CTRC cleaves the Leu81-Glu82 peptide bond and trypsin cleaves the Arg122-Val123 peptide bond; these 2 cleavages result in the eventual degradation of trypsinogen. CTRC also stimulates autoactivation of cationic trypsinogen by cleaving the Phe18-Asp19 peptide bond in the activation peptide. The shortened activation peptide is more susceptible to trypsin-mediated activation at the Lys23-Ile24 peptide bond. The dominant effect of CTRC is degradation. A: PRSS1 mutations can increase conversion of trypsinogen to trypsin by inhibition of CTRC-dependent trypsinogen degradation (red arrow) or by increasing CTRC-dependent stimulation of autoactivation (green arrow). See text for further details. B: proteolytic cleavage of human cationic trypsinogen by CTRC and trypsin. Primary structure of trypsinogen with disulfide bonds is shown. CTRC cleavage sites are highlighted in orange and trypsin cleavage sites are shown in blue. The activation peptide is in green. Note the yellow peptide segment not stabilized by disulfide bonds between the Leu 81 and Arg122 cleavage sites. $B$ is modified from Ref. 53, copyright by the National Academy of Sciences of the United States of America.

p.R116C is another example of a hereditary pancreatitis-associated mutation with variable penetrance. A recent study demonstrated that variant $\mathrm{p} . \mathrm{G} 208 \mathrm{~A}$ was associated with $\sim 4 \%$ of idiopathic and alcoholic chronic pancreatitis patients of Japanese origin, and increased disease risk by $\sim 15$ - to 20 -fold (32). This variant has no effect on trypsinogen activation but causes a moderate $(\sim 60 \%)$ reduction in trypsinogen secretion from transfected cells (46). Thus, as seen with variant p.R116C, mutation-induced misfolding and endoplasmic reticulum stress may be the pathologically relevant mechanism for variant p.G208A as well. It is also noteworthy that p.G208A is the first PRSS1 variant for which an association with alcoholic pancreatitis has been demonstrated.

Screening of various patient populations with sporadic idiopathic chronic pancreatitis has led to the identification of a large number of rare missense variants $(4,7,14,23,30,35,42$, $55,58)$. The clinical significance of such variants has been unclear because their low frequency did not allow statistical determination of genetic association with pancreatitis. Nevertheless, authors often described these as causative or pancreatitis-associated simply by analogy with well-characterized disease-relevant PRSSI mutations. Characterization of the functional phenotype of these variants revealed that only the activation peptide variant p.D19A increased autoactivation in a manner similar to the hereditary pancreatitis-associated activation-peptide mutations $(8,15,37)$. A handful of mutants showed a marked (p.D100H, p.C139F, and p.C139S) or moderate (p.K92N and p.S124F) secretion defect, which suggested that these mutations exerted their pathogenic effect through a mechanism that involves mutation-induced misfolding and endoplasmic reticulum stress, as described above for mutations p.R116C and p.G208A $(25,46)$. Another subset of mutants showed no phenotypic alterations compared with wild-type trypsinogen (p.L81M, p.Q98K, p.A121T, p.T137M, and p.S181G) or suffered increased degradation by CTRC (p.P36R, p.G83E, p.I88N, and p.V123M) $(46,52,54)$. These variants are likely harmless and their identification in patients with chronic pancreatitis may be accidental. One variant (p.K170E) caused slightly increased trypsinogen secretion, which, similarly to the copy number mutations, may translate to increased risk for pancreatitis (46).

Variant p.E79K should be highlighted because this is the only rare PRSS1 variant that was found not only in patients but also in unrelated controls $(3,7,20,23,41,50,59)$. Early biochemical studies demonstrated an increased propensity of this mutant to transactivate anionic trypsinogen; however, this small phenotypic change is unlikely to be of pathological consequence (59). More recent studies indicated that the rate of 
Review

PRSS1 VARIANTS IN PANCREATITIS

G469

Table 1. Variants in the PRSS1 gene encoding human cationic trypsinogen

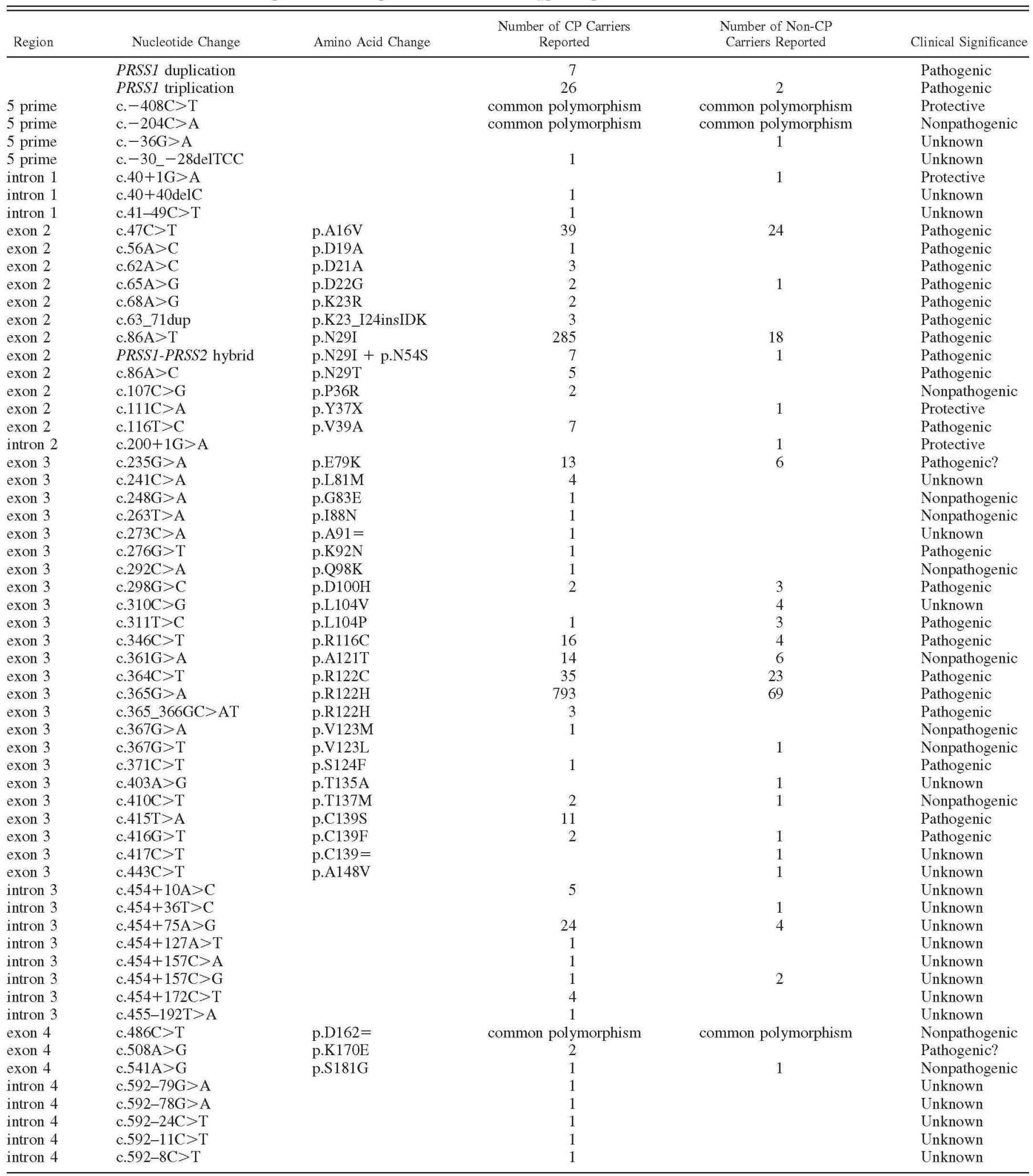


Table 1.-Continued

\begin{tabular}{|c|c|c|c|c|c|}
\hline Region & Nucleotide Change & $\begin{array}{c}\text { Amino Acid } \\
\text { Change }\end{array}$ & $\begin{array}{c}\text { Number of CP Carriers } \\
\text { Reported }\end{array}$ & $\begin{array}{l}\text { Number of Non-CP } \\
\text { Carriers Reported }\end{array}$ & Clinical Significance \\
\hline exon 5 & c. $623 \mathrm{G}>\mathrm{C}$ & p.G208A & 22 & 3 & Pathogenic \\
\hline exon 5 & c. $738 \mathrm{C}>\mathrm{T}$ & p. $\mathrm{N} 246=$ & common polymorphism & common polymorphism & Nonpathogenic \\
\hline
\end{tabular}

Adapted from www.pancreasgenetics.org, February 2, 2014. For a complete list of citations please visit the database website. The number of reported chronic

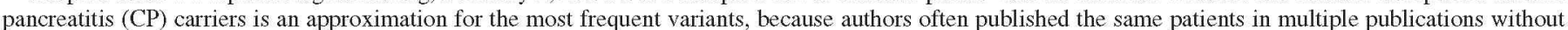

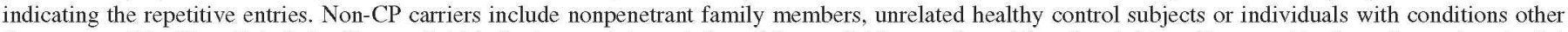

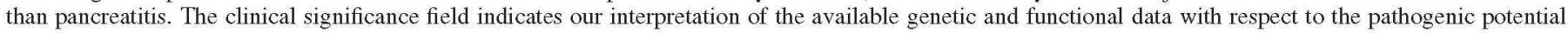

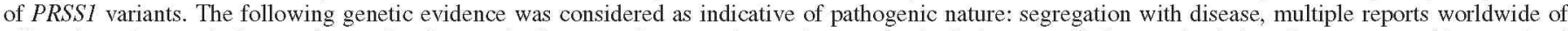

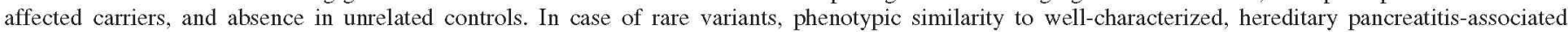

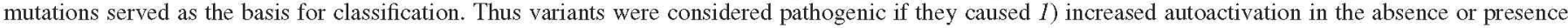

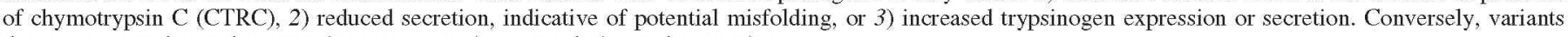
that are expected to reduce trypsinogen expression were designated protective.

autoactivation of mutant p.E79K is suppressed in the presence of CTRC; however, the mutant reaches higher final trypsin levels than wild-type trypsinogen, because of its resistance to CTRC-mediated degradation (A. Szabó and M. Sahin-Tóth, unpublished observations). Thus the biochemical phenotype is inconclusive but, together with the genetic data, may be cautiously interpreted as p.E79K being a mild pathogenic variant with low penetrance.

\section{PRSSI Variants in Conditions Unrelated to Pancreatitis}

Chen et al. (9) reported two loss-of-function PRSSI variants, a nonsense variant $\mathrm{p}$.Y37X and a splice-site mutation c. $200+1 \mathrm{G}>\mathrm{A}$ in intron 2 found in chronic alcoholics without pancreatic disease. The authors suggested that the variants should be protective against chronic pancreatitis. Gullo et al. (19) investigated PRSS1 variants in benign pancreatic hyper- enzymemia and found variant p.A148V and the splice-site mutation c. $40+1 \mathrm{G}>\mathrm{A}$ in intron 1 . Variant p.A148V has no functional consequences (A. Schnúr and M. Sahin-Tóth, unpublished observations), whereas variant c. $40+1 \mathrm{G}>\mathrm{A}$ should result in decreased trypsinogen expression, which might be protective against chronic pancreatitis. Two studies described PRSS1 variants in Chinese patients with pancreatic cancer (p.T135A, p.T137M, c. 454+36T $>$ C, and c. $454+157 \mathrm{C}>\mathrm{G}$ in intron 3), which are in all likelihood incidental findings unrelated to pathology $(13,68)$. The same group proposed a strong protective effect for the $\mathrm{C}$ allele of the common polymorphic variant c. $-408 \mathrm{C}>\mathrm{T}$ (erroneously reported as $-409 \mathrm{C} / \mathrm{T}$ ) against pancreatic cancer (31). Variant p.L104V was reported in two female members of a Chinese family with familial solid pseudopapillary tumor of the pancreas and in two healthy male relatives (17). Finally, patients with

Table 2. Mechanism of action of pathogenic PRSS1 variants

\begin{tabular}{|c|c|c|c|c|c|}
\hline Region & Nucleotide change & Amino acid change & Pathogenic mechanism & Notes & Citations \\
\hline & PRSS1 duplication & & increased secretion & no direct evidence & \\
\hline & PRSS1 triplication & & increased secretion & no direct evidence & \\
\hline exon 2 & c. $47 \mathrm{C}>\mathrm{T}$ & p.A16V & increased activation & CTRC dependent & 38,51 \\
\hline exon 2 & c. $.56 \mathrm{~A}>\mathrm{C}$ & p.D19A & increased activation & & $8,15,24,37$ \\
\hline exon 2 & c. $62 \mathrm{~A}>\mathrm{C}$ & p.D21A & increased activation & & 37 \\
\hline exon 2 & c. $65 \mathrm{~A}>\mathrm{G}$ & p.D22G & increased activation & & $8,15,22,24,57$ \\
\hline exon 2 & c. $68 \mathrm{~A}>\mathrm{G}$ & p.K23R & increased activation & & $8,15,24,57$ \\
\hline exon 2 & c. 63 _71dup & p.K23_I24insIDK & increased activation & & 15,22 \\
\hline exon 2 & c. $86 \bar{A}>\mathrm{T}$ & p.N29I & increased activation & CTRC dependent & 51 \\
\hline exon 2 & PRSS1-PRSS2 hybrid & p.N29I + p.N54S & increased activation & CTRC dependent & 51,60 \\
\hline exon 2 & c. $86 \mathrm{~A}>\mathrm{C}$ & p.N29T & increased activation & CTRC dependent & 51 \\
\hline exon 2 & c. $116 \mathrm{~T}>\mathrm{C}$ & p.V39A & increased activation & CTRC dependent & 51 \\
\hline exon 3 & c. $235 \mathrm{G}>\mathrm{A}$ & p.E79K & increased activation* & CTRC dependent & unpublished \\
\hline exon 3 & c. $276 \mathrm{G}>\mathrm{T}$ & p.K92N & misfolding & & $46^{1}$ \\
\hline exon 3 & c. $298 \mathrm{G}>\mathrm{C}$ & p.D100H & misfolding & & 46 \\
\hline exon 3 & c. $311 \mathrm{~T}>\mathrm{C}$ & p.L104P & misfolding & & unpublished \\
\hline exon 3 & c. $346 \mathrm{C}>\mathrm{T}$ & p.R116C & misfolding & & 25 \\
\hline exon 3 & c. $364 \mathrm{C}>\mathrm{T}$ & p.R122C & increased activation & CTRC dependent & 51 \\
\hline exon 3 & c. $365 \mathrm{G}>\mathrm{A}$ & p.R122H & increased activation & CTRC dependent & 51 \\
\hline exon 3 & c. $365 \_366 \mathrm{GC}>\mathrm{AT}$ & p.R122H & increased activation & CTRC dependent & 51 \\
\hline exon 3 & c. $371 \bar{C}>\mathrm{T}$ & p.S124F & misfolding & & 46 \\
\hline exon 3 & c. $415 \mathrm{~T}>\mathrm{A}$ & p.C139S & misfolding & & 25 \\
\hline exon 3 & c. $416 \mathrm{G}>\mathrm{T}$ & p.C139F & misfolding & & 46 \\
\hline exon 4 & c. $.508 \mathrm{~A}>\mathrm{G}$ & p.K170E & increased secretion & & 46 \\
\hline exon 5 & c. $623 \mathrm{G}>\mathrm{C}$ & p.G208A & misfolding & & 46 \\
\hline
\end{tabular}

See Table 1 for inclusion criteria. Mutations in PRSS1 can increase activation of cationic trypsinogen via 4 independent but mutually nonexclusive mechanisms: 1) inhibition of CTRC-dependent trypsinogen degradation, 2) increasing CTRC-dependent stimulation of autoactivation; 3) direct stimulation of autoactivation; and 4) increased trypsinogen secretion. Alternatively, PRSS1 mutations can cause misfolding and endoplasmic reticulum stress. See Fig. 1 for CTRC-dependent mechanisms of trypsinogen activation and degradation. *Note that the biochemical phenotype of p.E79K is ambiguous; see text for details. Citations refer to functional studies. 
PRSS1-related hereditary pancreatitis have a $40-55 \%$ lifetime risk of developing pancreatic cancer (Ref. 66 and references therein).

\section{The PRSS1 Database}

The first database for PRSS1 variants associated with chronic pancreatitis was created by Dr. Niels Teich at the University of Leipzig, Germany (61). Although the link is still active (http://www.uni-leipzig.de/pancreasmutation/db.html), the website has not been updated since 2006. To track the increasing number of PRSSI variants in the literature and to help with classification of their clinical relevance, in 2012 we created a new online database. Currently, the database lists 64 PRSS1 variants: 2 copy number mutations, 34 missense variants, 4 synonymous variants, 1 nonsense variant, 1 microinsertion, 1 hybrid gene, and 21 variants in noncoding regions (Table 1). With respect to clinical significance, 25 variants are pathogenic (Table 2), 14 are nonpathogenic, 4 variants are protective, and 21 (mostly intronic) variants have unknown significance. The database can be accessed at www.pancreasgenetics.org.

\section{Animal Models of PRSS1 Related Pancreatitis}

Although considerable progress has been made in clarifying the mechanism of PRSSI mutations at the biochemical level, animal models that recapitulate salient features of human hereditary pancreatitis are still lacking. At the time of writing this review, only two publications documented attempts to generate such models. Selig et al. (47) created transgenic mice with the coding DNA of human PRSSI containing the p.R122H mutation. The animals did not develop spontaneous pancreatitis, and cerulein caused only slightly more severe pancreatitis in transgenic mice relative to controls. Archer et al. (1) described the spontaneous development of acute and chronic pancreatitis in a transgenic line with the p.R122H mutation introduced into the coding DNA of mouse trypsinogen isoform T8. Unfortunately, independent replications or additional studies on this promising model have not been published since 2006. It is also unclear whether the observed phenotype was related to the expression of the mutant trypsinogen. Nevertheless, this study focused attention to the question whether the biochemical effects human PRSSI mutations would be similar in the context of mouse and human trypsinogens and whether we can make use of mouse trypsinogens to model the human disease. Recently, we demonstrated that the mouse pancreas expresses four trypsinogen isoforms to high levels (T7, T8, T9, and T20), and mouse Ctrc strongly inhibits autoactivation of isoforms T8 and T9 through cleavage of the autolysis loop (36). In sharp contrast to the human situation (see Ref. 51 and Fig. 1), mutation p.R122H had no appreciable effect on the autoactivation of T8 trypsinogen in the presence of mouse Ctrc (36). These observations argue that human pancreatitis-associated mutations may not recapitulate the pathogenic biochemical phenotype in the context of mouse trypsinogens.

Genetic deletion of mouse T7 was recently shown to abolish intra-acinar trypsinogen activation in response to hyperstimulation with cerulein, whereas severity of acute pancreatitis was somewhat decreased but not diminished (11). Furthermore, development of cerulein-induced chronic pancreatitis was un- affected by the absence of T7 (44). These observations seem to call into question the direct role of trypsinogen in the development of pancreatitis and seem to be at odds with the preponderance of human genetic and biochemical data discussed in this review. However, a more likely explanation for the apparent contradiction is that the hyperstimulation model employed in these studies does not mimic the pathological pathway associated with human hereditary pancreatitis. Future studies will be needed to shed more light on this intriguing problem.

\section{ACKNOWLEDGMENTS}

The authors acknowledge the contributions of János Borbás, as webmaster for the www.pancreasgenetics.org website.

\section{GRANTS}

Studies in the senior author's laboratory were supported by NIH grants R01DK058088, R01DK082412, and R01DK095753.

\section{DISCLOSURES}

No conflicts of interest, financial or otherwise, are declared by the author(s).

\section{AUTHOR CONTRIBUTIONS}

B.C.N. and M.S.-T. conception and design of research; B.C.N. and M.S.-T prepared figures; B.C.N. and M.S.-T. drafted manuscript; B.C.N. and M.S.-T. edited and revised manuscript; B.C.N. and M.S.-T. approved final version of manuscript.

\section{REFERENCES}

1. Archer H, Jura N, Keller J, Jacobson M, Bar-Sagi D. A mouse model of hereditary pancreatitis generated by transgenic expression of $\mathrm{R} 122 \mathrm{H}$ trypsinogen. Gastroenterology 131: 1844-1855, 2006.

2. Arduino C, Salacone P, Pasini B, Brusco A, Salmin P, Bacillo E, Robecchi A, Cestino L, Cirillo S, Regge D, Cappello N, Gaia E. Association of a new cationic trypsinogen gene mutation (V39A) with chronic pancreatitis in an Italian family. Gut 54: 1663-1664, 2005.

3. Bernardino AL, Guarita DR, Mott CB, Pedroso MR, Machado MC, Laudanna AA, Tani CM, Almeida FL, Zatz M. CFTR, PRSS1 and SPINK1 mutations in the development of pancreatitis in Brazilian patients. JOP 4: 169-177, 2003 .

4. Chang YT, Wei SC, Tien YWLPC, Jan IS, Su YN, Wong JM, Chang MC. Association and differential role of PRSS1 and SPINK1 mutation in early-onset and late-onset idiopathic chronic pancreatitis in Chinese subjects. Gut 58: 885, 2009.

5. Chauvin A, Chen JM, Quemener S, Masson E, Kehrer-Sawatzki H, Ohmle B, Cooper DN, Le Maréchal C, Férec C. Elucidation of the complex structure and origin of the human trypsinogen locus triplication. Hum Mol Genet 18: 3605-3614, 2009.

6. Chen JM, Ferec C. Gene conversion-like missense mutations in the human cationic trypsinogen gene and insights into the molecular evolution of the human trypsinogen family. Mol Genet Metab 71: 463-469, 2000.

7. Chen JM, Piepoli Bis A, Le Bodic L, Ruszniewski P, Robaszkiewicz M, Deprez PH, Raguenes O, Quere I, Andriulli A, Ferec C. Mutational screening of the cationic trypsinogen gene in a large cohort of subjects with idiopathic chronic pancreatitis. Clin Genet 59: 189-193, 2001.

8. Chen JM, Kukor Z, Le Maréchal C, Tóth M, Tsakiris L, Raguénès $\mathbf{O}$, Férec C, Sahin-Tóth M. Evolution of trypsinogen activation peptides. Mol Biol Evol 20: 1767-1777, 2003.

9. Chen JM, Le Maréchal C, Lucas D, Raguénès O, Férec C. "Loss of function" mutations in the cationic trypsinogen gene (PRSS1) may act as a protective factor against pancreatitis. Mol Genet Metab 79: 67-70, 2003.

10. Comfort MW, Steinberg AG. Pedigree of a family with hereditary chronic relapsing pancreatitis. Gastroenterology 21: 54-63, 1952.

11. Dawra R, Sah RP, Dudeja V, Rishi L, Talukdar R, Garg P, Saluja AK. Intra-acinar trypsinogen activation mediates early stages of pancreatic injury but not inflammation in mice with acute pancreatitis. Gastroenterology 141: 2210-2217, 2011.

12. Férec C, Raguénès $\mathbf{O}$, Salomon $\mathbf{R}$, Roche C, Bernard JP, Guillot M, Quéré I, Faure C, Mercier B, Audrézet MP, Guillausseau PJ, Dupont 
C, Munnich A, Bignon JD, Le Bodic L. Mutations in the cationic trypsinogen gene and evidence for genetic heterogeneity in hereditary pancreatitis. J Med Genet 36: 228-232, 1999.

13. Gao F, Liu QC, Zhang $\mathbf{S}$, Zhuang ZH, Lin CZ, Lin XH. PRSS1 intron mutations in patients with pancreatic cancer and chronic pancreatitis. Mol Med Rep 5: 449-451, 2012.

14. Gao F, Li YM, Hong GL, Xu ZF, Liu QC, He QL, Lin LQ, Weng SH. PRSS1_p Leu81Met mutation results in autoimmune pancreatitis. World $J$ Gastroenterol 19: 3332-3338, 2013 .

15. Geisz A, Hegyi P, Sahin-Tóth M. Robust autoactivation, chymotrypsin C independence and diminished secretion define a subset of hereditary pancreatitis-associated cationic trypsinogen mutants. FEBS $J$ 280: $2888-$ 2899, 2013.

16. Gorry MC, Gabbaizedeh D, Furey W, Gates LK Jr, Preston RA, Aston CE, Zhang Y, Ulrich C, Ehrlich GD, Whitcomb DC. Mutations in the cationic trypsinogen gene are associated with recurrent acute and chronic pancreatitis. Gastroenterology 113: 1063-1068, 1997.

17. Gou S, Yu J, Wang C, Liu T, Cui P, Li X. Three female familial cases of solid pseudopapillary tumors with a protease serine 1 gene mutation. Pancreas 42: 168-173, 2013.

18. Grocock CJ, Rebours V, Delhaye MN, Andrén-Sandberg A, Weiss FU, Mountford R, Harcus MJ, Niemczyck E, Vitone LJ, Dodd S, Jørgensen MT, Ammann RW, Schaffalitzky de Muckadell O, Butler JV, Burgess P, Kerr B, Charnley R, Sutton R, Raraty MG, Devière J, Whitcomb DC, Neoptolemos JP. Lévy P, Lerch MM, Greenhalf W; European Registry of Hereditary Pancreatitis, and Pancreatic Cancer. The variable phenotype of the $\mathrm{p}$. A16V mutation of cationic trypsinogen (PRSS1) in pancreatitis families. Gut 59: 357-363, 2010.

19. Gullo L, Laghi L, Migliori M, Lucrezio L, Bianchi P, Randolph AE, Mantovani V, Bastagli L, Pezzilli R, Malesci A. SPINK1 and PRSS1 mutations in benign pancreatic hyperenzymemia. Pancreas 37: 31-35, 2008.

20. Hamoir C, Pepermans X, Piessevaux H, Jouret-Mourin A, Weynand B, Habyalimana JB, Leal T, Geubel A, Gigot JF, Deprez PH. Clinical and morphological characteristics of sporadic genetically determined pancreatitis as compared to idiopathic pancreatitis: higher risk of pancreatic cancer in CFTR variants. Digestion 87: 229-239, 2013.

21. Howes N, Lerch MM, Greenhalf W, Stocken DD, Ellis I, Simon P, Truninger K, Ammann R, Cavallini G, Charnley RM, Uomo G, Delhaye M, Spicak J, Drumm B, Jansen J, Mountford R, Whitcomb DC, Neoptolemos JP; European Registry of Hereditary Pancreatitis, and Pancreatic Cancer (EUROPAC). Clinical and genetic characteristics of hereditary pancreatitis in Europe. Clin Gastroenterol Hepatol 2: 252-261, 2004.

22. Joergensen MT, Geisz A, Brusgaard K, Schaffalitzky de Muckadell OB, Hegyi P, Gerdes AM, Sahin-Tóth M. Intragenic duplication: a novel mutational mechanism in hereditary pancreatitis. Pancreas 40: 540-546, 2011.

23. Keiles S, Kammesheidt A. Identification of CFTR, PRSSI, and SPINKI mutations in 381 patients with pancreatitis. Pancreas 33:221-227, 2006

24. Kereszturi E, Sahin-Tóth M. Intracellular autoactivation of human cationic trypsinogen mutants causes reduced trypsinogen secretion and acinar cell death. $J$ Biol Chem 284: 33392-33399, 2009.

25. Kereszturi E, Szmola R, Kukor Z, Simon P, Weiss FU, Lerch MM, Sahin-Tóth M. Hereditary pancreatitis caused by mutation-induced misfolding of human cationic trypsinogen: a novel disease mechanism. Hum Mutat 30: 575-582, 2009

26. LaRusch J, Barmada MM, Solomon S, Whitcomb DC. Whole exome sequencing identifies multiple, complex etiologies in an idiopathic hereditary pancreatitis kindred. JOP 13: 258-262, 2012.

27. Le Bodic L, Bignon JD, Raguénès $\boldsymbol{O}$, Mercier B, Georgelin T, Schnee M, Soulard F, Gagne K, Bonneville F, Muller JY, Bachner L, Férec C. The hereditary pancreatitis gene maps to long arm of chromosome 7. Hum Mol Genet 5: 549-554, 1996.

28. Le Maréchal C, Chen JM, Quéré I, Raguénès O, Férec C, Auroux J. Discrimination of three mutational events that result in a disruption of the R122 primary autolysis site of the human cationic trypsinogen (PRSS1) by denaturing high performance liquid chromatography. BMC Genet 2: 19 , 2001

29. Le Maréchal C, Masson E, Chen JM, Morel F, Ruszniewski P, Levy P, Férec C. Hereditary pancreatitis caused by triplication of the trypsinogen locus. Nat Genet 38: 1372-1374, 2006.

30. Lee YJ, Kim KM, Choi JH, Lee BH, Kim GH, Yoo HW. High incidence of PRSSI and SPINKI mutations in Korean children with acute recurrent and chronic pancreatitis. I Pediatr Gastroenterol Nutr 52: 478-481, 2011.

31. Liu Q, Lin X, Liu J, Liu A, Gao F. The -409 C/T genotype of PRSS1 protects against pancreatic cancer in the Han Chinese population. Dig Dis Sci 57: 573-579, 2012.

32. Masamune A, Nakano E, Kume K, Takikawa T, Kakuta Y, Shimosegawa T. PRSS1 c.623G $>$ C (p.G208A) variant is associated with pancreatitis in Japan. Gut 63, 366, 2014.

33. Masson E, Le Maréchal C, Chandak GR, Lamoril J, Bezieau S, Mahurkar S, Bhaskar S, Reddy DN, Chen JM, Férec C. Trypsinogen copy number mutations in patients with idiopathic chronic pancreatitis. Clin Gastroenterol Hepatol 6: 82-88, 2008.

34. Masson E, Le Maréchal C, Delcenserie R, Chen JM, Férec C. Hereditary pancreatitis caused by a double gain-of-function trypsinogen mutation. Hum Genet 123: 521-529, 2008.

35. Masson E, Hammel P, Garceau C, Bénech C, Quéméner-Redon S, Chen JM, Férec C. Characterization of two deletions of the CTRC locus. Mol Genet Metab 109: 296-300, 2013.

36. Németh BC, Wartmann T, Halangk W, Sahin-Tóth M. Autoactivation of mouse trypsinogens is regulated by chymotrypsin $\mathrm{C}$ via cleavage of the autolysis loop. J Biol Chem 288: 24049-24062, 2013.

37. Nemoda Z, Sahin-Tóth M. The tetra-aspartate motif in the activation peptide of human cationic trypsinogen is essential for autoactivation control but not for enteropeptidase recognition. J Biol Chem 280: 29645$29652,2005$.

38. Nemoda Z, Sahin-Tóth M. Chymotrypsin C (caldecrin) stimulates autoactivation of human cationic trypsinogen. $J$ Biol Chem 281: 11879-11886, 2006.

39. Pandya A, Blanton SH, Landa B, Javaheri R, Melvin E, Nance WE, Markello T. Linkage studies in a large kindred with hereditary pancreatitis confirms mapping of the gene to a $16-\mathrm{cM}$ region on $7 \mathrm{q}$. Genomics 38 : 227-230, 1996.

40. Pfützer R, Myers E, Applebaum-Shapiro S, Finch R, Ellis I, Neoptolemos J, Kant JA, Whitcomb DC. Novel cationic trypsinogen (PRSS1) N29T and R122C mutations cause autosomal dominant hereditary pancreatitis. Gut 50: 271-272, 2002.

41. Rebours V, Boutron-Ruault MC, Schnee M, Férec C, Le Maréchal C, Hentic O, Maire F, Hammel P, Ruszniewski P, Lévy P. The natural history of hereditary pancreatitis: a national series. Gut 58: 97-103, 2009.

42. Rosendahl J, Landt O, Bernadova J, Kovacs P, Teich N, Bödeker H, Keim V, Ruffert C, Mössner J, Kage A, Stumvoll M, Groneberg D, Krüger R, Luck W, Treiber M, Becker M, Witt H. CFTR, SPINKI, CTRC and PRSS1 variants in chronic pancreatitis; is the role of mutated CFTR overestimated? Gut 62: 582-592, 2013.

43. Rowen L, Koop BF, Hood L. The complete 685-kilobase DNA sequence of the human beta T cell receptor locus. Science 272: 1755-1762, 1996.

44. Sah RP, Dudeja V, Dawra RK, Saluja AK. Caerulein-induced chronic pancreatitis does not require intra-acinar activation of trypsinogen in mice. Gastroenterology 144: 1076-1085, 2013.

45. Scheele G, Bartelt D, Bieger W. Characterization of human exocrine pancreatic proteins by two-dimensional isoelectric focusing/sodium dodecyl sulfate gel electrophoresis. Gastroenterology 80: 461-473, 1981.

46. Schnúr A, Beer S, Witt H, Hegyi P, Sahin-Tóth M. Functional effects of 13 rare PRSSI variants presumed to cause chronic pancreatitis. Gut 63: 337-343, 2014.

47. Selig L, Sack U, Gaiser S, Klöppel G, Savkovic V, Mössner J, Keim V, Bödeker H. Characterisation of a transgenic mouse expressing R122H human cationic trypsinogen. BMC Gastroenterol 6: 30, 2006.

48. Simon P, Weiss FU, Sahin-Tóth M, Parry M, Nayler O, Lenfers B, Schnekenburger J, Mayerle J, Domschke W, Lerch MM. Hereditary pancreatitis caused by a novel PRSS1 mutation (Arg-122 $\rightarrow$ Cys) that alters autoactivation and autodegradation of cationic trypsinogen. $J$ Biol Chem 277: 5404-5410, 2002.

49. Solomon S, Gelrud A, Whitcomb DC. Low penetrance pancreatitis phenotype in a Venezuelan kindred with a PRSS1 R122H mutation. JOP 14: 187-189, 2013.

50. Sultan M, Werlin S, Venkatasubramani N. Genetic prevalence and characteristics in children with recurrent pancreatitis. $J$ Pediatr Gastroenterol Nutr 54: 645-650, 2012.

51. Szabó A, Sahin-Tóth M. Increased activation of hereditary pancreatitisassociated human cationic trypsinogen mutants in presence of chymotrypsin C. J Biol Chem 287: 20701-20710, 2012. 
52. Szabó A, Sahin-Tóth M. Determinants of chymotrypsin C cleavage specificity in the calcium-binding loop of human cationic trypsinogen. FEBS J 279, 4283-4292, 2012.

53. Szmola R, Sahin-Tóth M. Chymotrypsin C (caldecrin) promotes degradation of human cationic trypsin: identity with Rinderknecht's enzyme Y. Proc Natl Acad Sci USA 104: 11227-11232, 2007.

54. Szmola R, Sahin-Tóth M. Uncertainties in the classification of human cationic trypsinogen (PRSS1) variants as hereditary pancreatitis-associated mutations. J Med Genet 47: 348-350, 2010.

55. Tautermann G, Ruebsamen H, Beck M, Dertinger S, Drexel H, Lohse P. R116C mutation of cationic trypsinogen in a Turkish family with recurrent pancreatitis illustrates genetic microheterogeneity of hereditary pancreatitis. Digestion 64: 226-232, 2001.

56. Teich N, Mössner J, Keim V. Mutations of the cationic trypsinogen in hereditary pancreatitis. Hum Mutat 12: 39-43, 1998.

57. Teich N, Ockenga J, Hoffimeister A, Manns M, Mössner J, Keim V. Chronic pancreatitis associated with an activation peptide mutation that facilitates trypsin activation. Gastroenterology 119: 461-465, 2000.

58. Teich N, Bauer N, Mössner J, Keim V. Mutational screening of patients with nonalcoholic chronic pancreatitis: identification of further trypsinogen variants. Am J Gastroenterol 97: 341-346, 2002.

59. Teich N, Le Maréchal C, Kukor Z, Caca K, Witzigmann H, Chen JM, Tóth M, Mössner J, Keim V, Férec C, Sahin-Tóth M. Interaction between trypsinogen isoforms in genetically determined pancreatitis: mutation E79K in cationic trypsin (PRSS1) causes increased transactivation of anionic trypsinogen (PRSS2). Hum Mutat 23: 22-31, 2004.

60. Teich N, Nemoda Z, Kohler H, Heinritz W, Mössner J, Keim V, Sahin-Tóth M. Gene conversion between functional trypsinogen genes PRSS1 and PRSS2 associated with chronic pancreatitis in a six-year-old girl. Hum Mutat 25: 343-347, 2005.

61. Teich N, Rosendahl J, Tóth M, Mössner J, Sahin-Tóth M. Mutations of human cationic trypsinogen (PRSSI) and chronic pancreatitis. Hum Mutat 27: 721-730, 2006.
62. Whitcomb DC, Preston RA, Aston CE, Sossenheimer MJ, Barua PS, Zhang Y, Wong-Chong A, White GJ, Wood PG, Gates LK Jr, Ulrich C, Martin SP, Post JC, Ehrlich GD. A gene for hereditary pancreatitis maps to chromosome 7q35. Gastroenterology 110: 1975-1980, 1996.

63. Whitcomb DC, Gorry MC, Preston RA, Furey W, Sossenheimer MJ, Ulrich CD, Martin SP, Gates LK Jr, Amann ST, Toskes PP, Liddle R, McGrath K, Uomo G, Post JC, Ehrlich GD. Hereditary pancreatitis is caused by a mutation in the cationic trypsinogen gene. Nat Genet 14: 141-145, 1996.

64. Whitcomb DC, Larusch J, Krasinskas AM, Klei L, Smith JP, Brand RE, Neoptolemos JP, Lerch MM, Tector M, Sandhu BS, Guda NM, Orlichenko L; Alzheimer's Disease Genetics Consortium, Alkaade S, Amann ST, Anderson MA, Baillie J, Banks PA, Conwell D, Coté GA, Cotton PB, Disario J, Farrer LA, Forsmark CE, Johnstone M, Gardner TB, Gelrud A, Greenhalf W, Haines JL, Hartman DJ, Hawes RA, Lawrence C, Lewis M, Mayerle J, Mayeux R, Melhem NM, Money ME, Muniraj T, Papachriston GI, Pericak-Vance MA, Romagnuolo J, Schellenberg GD, Sherman S, Simon P, Singh VP, Slivka A, Stolz D, Sutton R, Weiss FU, Wilcox CM, Zarnescu NO, Wisniewski SR, O'Connell MR, Kienholz ML, Roeder K, Barmada MM, Yadav D, Devlin B. Common genetic variants in the CLDN2 and PRSS1-PRSS2 loci alter risk for alcohol-related and sporadic pancreatitis. Nat Genet 44: 1349-1354, 2012.

65. Witt H, Luck W, Becker M. A signal peptide cleavage site mutation in the cationic trypsinogen gene is strongly associated with chronic pancreatitis. Gastroenterology 117: 7-10, 1999.

66. Yadav D, Lowenfels AB. The epidemiology of pancreatitis and pancreatic cancer. Gastroenterology 144: 1252-1261, 2013.

67. Yilmaz B, Ekız F, Karakaş E, Aykut A, Sımşek Z, Çoban S, Onay H, Özkmay F. A rare PRSS1 mutation in a Turkish family with hereditary chronic pancreatitis. Turk J Gastroenterol 23: 826-827, 2012.

68. Zeng K, Liu QC, Lin JH, Lin XH, Zhuang ZH, Gao F, Ou QS. Novel mutations of PRSS1 gene in patients with pancreatic cancer among Han population. Chin Med J (Engl) 124: 2065-2067, 2011. 